\title{
Skurðmeðferð lifrarfrumukrabbameins á Landspítala 1993-2012
}

\author{
Anna Kristín Höskuldsdóttir ${ }^{1}$ æknir, Sigurður Blöndal ${ }^{1}$ læknir, Jón Gunnlaugur Jónasson ${ }^{2,3}$ læknir, \\ Kristín Huld Haraldsdóttir ${ }^{1,2}$ ææknir
}

\section{Á G R I P}

Inngangur: Lifrarfrumukrabbamein er meðal algengustu krabbameina í heimi. Nýgengi á Íslandi er með pví lægsta sem pekkist og er helsta ástæða pess talin lág tíðni á skorpulifur. Læknandi meðferð felur í sér skurðaðgerð með lifrarígræðslu eða hlutabrottnámi á lifur, en einungis um 30\% sjúklinga eru skurðtækir við greiningu. Markmið pessarar rannsóknar var að kanna hversu margir sjúklingar gangast undir lifrarbrottnám vegna lifrarfrumukrabbameins á Landspítala og kanna árangur skurðaðgerða. Efniviður og aðferðir: Rannsóknin var afturskyggn býðisrannsókn sem náđi til allra peirra einstaklinga 18 ára og eldri sem gengust undir skurðaðgerð við lifrarfrumukrabbameini á Landspítala frá 1. janúar 1993 til 31. desember 2012. Upplýsingum var safnað úr sjúkraskrám. Notast var við lýsandi tölfræð̇i.

Niðurstöður: Á tímabilinu gengust 22 einstaklingar undir hlutabrottnám lifrar, par af 12 (55\%) í stærri lifraraðgerð. Í heildina greindust 105 einstak- lingar með lifrarfrumukrabbamein, 6 fóru i lifrarígræðslu og alls gengust 28 (27\%) einstaklingar undir skurðaðgerð. Meðalstærð æxla var $8,5 \mathrm{~cm}$ (3-22). Fjórir einstaklingar voru með skorpulifur. Tíðni alvarlegra fylgikvilla í aðgerð var 23\% og eftir aðgerð $32 \%$ (Clavien-Dindo flokkar III og IV). Alls purftu prír enduraðgerð. Enginn sjúklingur lést innan 30 daga frá aðgerð. Tólf sjúklingar höfðu greinst með endurkomu á sjúkdómi (55\%) við lok rannsóknartímabilsins og 11 létust. 23\% aðgerðarsjúklinga létust innan árs frá aðgerð.

Ályktun: Eins og sýnt hefur verið fram á erlendis er hlutfall skurðtækra einstaklinga með lifrarfrumukrabbamein á íslandi lágt. Lágt hlutfall peirra sem greinast eru með skorpulifur eða pekktan undirliggjandi lifrarsjúkdóm. Tíoni alvarlegra fylgikvilla er hærri hér en í erlendum rannsóknum, sem skýrist að öllum líkindum af pví að um mun stærri æxli er að ræða, en dánartíóni er sambærileg.

\section{Inngangur}

Lifrarfrumukrabbamein (Hepatocellular carcinoma, HCC) er illvígt krabbamein sem greinist seint og eru horfur slæmar. Раð er meðal algengustu krabbameina í heimi en tíðni er breytileg eftir landssvæðum og er hæst par sem lifrarbólguveira B er landlæg. ${ }^{1}$ Meirihluti peirra sem greinast með lifrarfrumukrabbamein á heimsvísu eru með skorpulifur, eða um $80 \%,{ }^{2}$ en einungis $32 \%$ hér á Íslandi. ${ }^{3}$ Á Íslandi er aldursstaðlað nýgengi lifrarfrumukrabbameins 1,08 á 100.000 íbúa og er pað með pví lægsta sem pekkist í heiminum og er ástæða pess talin vera lág tíðni skorpulifrar. ${ }^{3}$

Læknandi meðferð við lifrarfrumukrabbameini felur í sér skurðaðgerð en einungis 30\% eru skurðtækir við greiningu. ${ }^{5,6}$ Möguleiki á skurðaðgerð veltur meðal annars á stigun krabbameins og alvarleika undirliggjandi lifrarsjúkdóms. Mögulegar skurðaðgerðir eru lifrarígræðsla og hlutabrottnám á lifur.

Kjörmeðferð við lifrarfrumukrabbameini hjá sjúklingum með skorpulifur er lifrarígræðsla en til pess að gangast undir slíka aðgerð parf sjúklingur að uppfylla ákveðin skilmerki og notast flestir við svokölluð Milan eða UCSF (University of Californa, San Francisco $)^{7}$ skilmerki. Milan-skilmerki fela í sér að sjúklingur

'Skurðlækningadeild Landspítala, ${ }^{2}$ æknadeild Háskóla Íslands, ${ }^{3}$ rannsóknarstofu í meinafræði. Fyrirspurnum svarar Anna Kristín Höskuldsdóttir, annakh26@gmail.com

https://doi.org/10.17992//bl.2017.11.158

Greinin barst blađinu 24. apríl 2017, sampykkt til birtingar 2. október 2017. hafi eitt æxli sem er minna en $5 \mathrm{~cm}$ eða prjú æxli hvert um sig minna en $3 \mathrm{~cm}$, en USCF eitt æxli sem er minna en 6,5 cm eða prjú æxli hvert um sig minna en $4,5 \mathrm{~cm}$ og að heildaræxlisstærð fari ekki yfir $8 \mathrm{~cm}$. Bæði skilmerki fela í sér að sjúkdómurinn sé staðbundinn við lifrina og æðainnvöxtur sé ekki til staðar. Sjúklingar sem uppfylla pessi skilmerki hafa 70\% 5 ára lifun og tæplega $10 \%$ endurkomutíðni. Kosturinn við lifrarígræðslu er að verið er að fjarlægja krabbameinið sjálft ásamt undirliggjandi langvinnum lifrarsjúkdómi og ekki pörf á að skilja eftir nægjanlegan starfshæfan lifrarvef og pví minni líkur á staðbundinni endurkomu. Aftur á móti parf ónæmisbælandi meðferð í kjölfar lifrarígræðslu og einnig er skortur á líffæragjöfum og verða pví margir óskurðtækir á meðan peir bíða eftir ígræðslu, eða um 15-35\% peirra sem eru á biðlista í Evrópu. ${ }^{8}$ Hlutabrottnám er nú fyrsti meðferðarkostur fyrir lifrarfrumukrabbamein par sem skorpulifur er ekki til staðar. ${ }^{9-11}$ Pá er æxlið fjarlægt með nægjanlegum heilbrigðum lifrarvef í kring til að hreinar skurðbrúnir náist. Nauðsynlegt er að skilið sé eftir nægilegt magn af starfhæfum lifrarvef til að minnka líkur á lifrarbilun eftir aðgerð. Ef skorpulifur er ekki til staðar nægir að sjúklingur hafi $25 \%$ af starfhæfum lifrarvef, ${ }^{12}$ tvo samliggjandi lifrargeira í pað minnsta og gott að- og fráflæði frá peim vef sem skilinn er eftir. Við skorpulifur parf að meta stig lifrarsjúkdóms (Child-Pugh-skor, tafla I) en sjúklingar með stig A og einstaka með stig B pola takmarkaða aðgerð með hlutabrottnámi (minna en tvo lifrargeira).$^{13}$ Hlutabrottnám á lifur getur verið annaðhvort líffærafræðilegt (anatomic) eða ekki (non-anatomic). Við líffærafræðilegt 
Tafla I. Child-Pugh-flokkun fyrir skorpulifur: A 5-6 stig, B 7-9 stig og C 10-15 stig.

\begin{tabular}{lccc}
\hline & 1 stig & 2 stig & 3 stig \\
\hline $\begin{array}{l}\text { S-bilirúbín } \\
(\mu \mathrm{mol} / \mathrm{l})\end{array}$ & $<34$ & $34-50$ & $>50$ \\
\hline S-albúmín (g/L) & $>35$ & $28-35$ & $<28$ \\
\hline PT (sek) & $<4$ & $4-6$ & $>6$ \\
\hline Skinuholsvökvi & Enginn & Vægur & Mikill \\
\hline Lifrarheilakvilli & Ekki til staðar & Minniháttar & $\begin{array}{c}\text { Alvarlegt } \\
\text { (meðvitundarskerðing) }\end{array}$ \\
\hline
\end{tabular}

brottnám er farið eftir skiptingu lifrarinnar í geira sem kennd er við Couinaud ${ }^{14}$ (mynd 1) og er petta betri valkostur með betri útkomu eftir aðgerð, bæði til lengri og skemmri tíma. ${ }^{15}$

Á undanförnum áratugum hefur fylgikvilla- og dánartíðni í kjölfar lifrarbrottnáms lækkað margfalt, pökk sé betri aðgerðartækni, betra sjúklingavali og betri eftirmeðferð svo eitthvað sé nefnt. Fylgikvillatíðnin er pó enn há og hækkar eftir pví sem æxlið er stærra og/eða lifrarstarfsemi lélegri, eða allt frá 4-48\% samkvæmt erlendum rannsóknum. ${ }^{16}$ Alvarlegir fylgikvillar verða hjá um $20 \%$ sjúklinga og eru meðal annars gallleki, ýmsir lungnafylgikvillar, bráð nýrnabilun og lifrarbilun. ${ }^{1718}$ Dánartíðni í tengslum við hlutabrottnám á lifur er allt að $10 \%{ }^{16}$ og er lægst par sem flestar aðgerðir eru framkvæmdar, eða $<3 \% .^{18}$ Helstu forspárpættir fyrir skurðdauða eru undirliggjandi nýrnasjúkdómur og skorpulifur. ${ }^{19,20}$

Fimm ára lifun eftir lifrarbrottnám vegna lifrarfrumukrabbameins er 26-55\% samkvæmt erlendum rannsóknum en endurkomutíðni er há, eða allt að 80\% innan 5 ára. ${ }^{21}$ Áhættupættir fyrir endurkomu eru stærð æxlis, æxli í eða nálægt skurðbrún, skorpulifur, innvöxtur æxlis í æðar, æxli af hárri gráðu, fjöldi hnúta og smáæða segamyndun. ${ }^{22,23}$ Helsta dánarorsök í kjölfar brottnáms á lifur, hvort sem skorpulifur er til staðar eða ekki, er endurkoma æxlis og látast flestir innan árs frá endurkomu. ${ }^{22,23}$

Markmið rannsóknarinnar var að kanna hversu margir sjúklingar gangast undir lifrarbrottnám vegna lifrarfrumukrabbameins á Landspítala og kanna árangur skurðaðgerða.

Tafla II. Clavien-Dindo-flokkun á fylgikvillum eftir skurðaðgerðir. ${ }^{2}$ Gráða Skilgreining

Gráđa 1 Öll frávik frá eðlilegum gangi eftir skurðaðgerð par sem ekki er pörf á lyfjameðferð, skurðmeðferð, speglun né röntgenstýrðu inngripi. Leyfileg meðferð er: ógleðilyf, hitalækkandi, verkjalyf, pvagræsandi, sölt og sjúkrapjálfun. Á einnig við um sárasýkingar sem eru opnaðar á deild.

Gráđa 2 Parfnast meðferðar með lyfjum öðrum en peim sem eru talin upp að ofan, blóđgjafir og næring í æð.

Gráða 3 Parfnast skurðaðgerðar, speglunar eða röntgenstýrðs inngrips.

\begin{aligned} & \hline $3 a$ Inngrip án svæfingar \\ & \hline $3 b$ Inngrip með svæfingu \\ & \hline\end{aligned}

Gráða 4 Lífshættulegir fylgikvillar sem parfnast meðferðar á gjörgæsludeild

4a Líffærabilun tengd einu líffærakerfi

4b Fjölkerfabilun

Gráđa 5 Dauði sjúklings

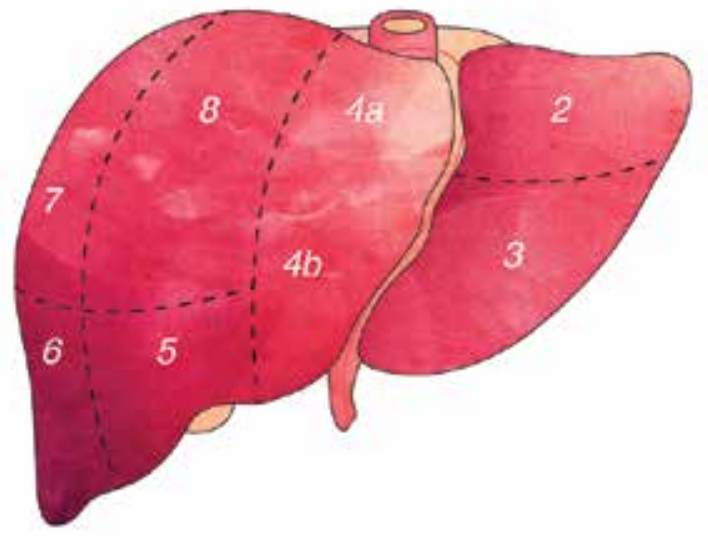

Mynd 1. Skipting lifrar í geira (Couinaud segments). Mynd: Iona Sjöfn Huntingdon-Williams

\section{Efniviður og aðferðir}

Rannsóknin var afturskyggn pýðisrannsókn og náði til allra peirra einstaklinga 18 ára og eldri sem greindust með lifrarfrumukrabbamein og gengust undir skurðaðgerð á Landspítala á 20 ára tímabili frá 1. janúar 1993 til 31. desember 2012.

Sjúklingahópurinn var fundinn með leit í sjúkdóma- og aðgerðarskrám Landspítalans. Leitað var eftir aðgerðarkóðum fyrir lifrarbrottnám (JJSA41, JJSA43, JJSA20, JJSB00, JJSB10, JJSB20, JJSB30, JJSB40, JJSB50, JJSB53, JJSB60, JJSB96) og einnig eftir greiningarnúmerum fyrir lifrarfrumukrabbamein (1550 og C22).

Klínískum upplýsingum var safnað úr sjúkraskrám, aðgerðarlýsingum, meinafræðisvörum og svæfingarskýrslum, meðal annars um aldur og kyn sjúklinga, áhættupætti skorpulifrar, vefjagreiningu og aðgerð ásamt fylgikvillum. Fylgikvillar í og eftir aðgerð voru skráðir og fylgikvillar eftir aðgerð flokkaðir sam-

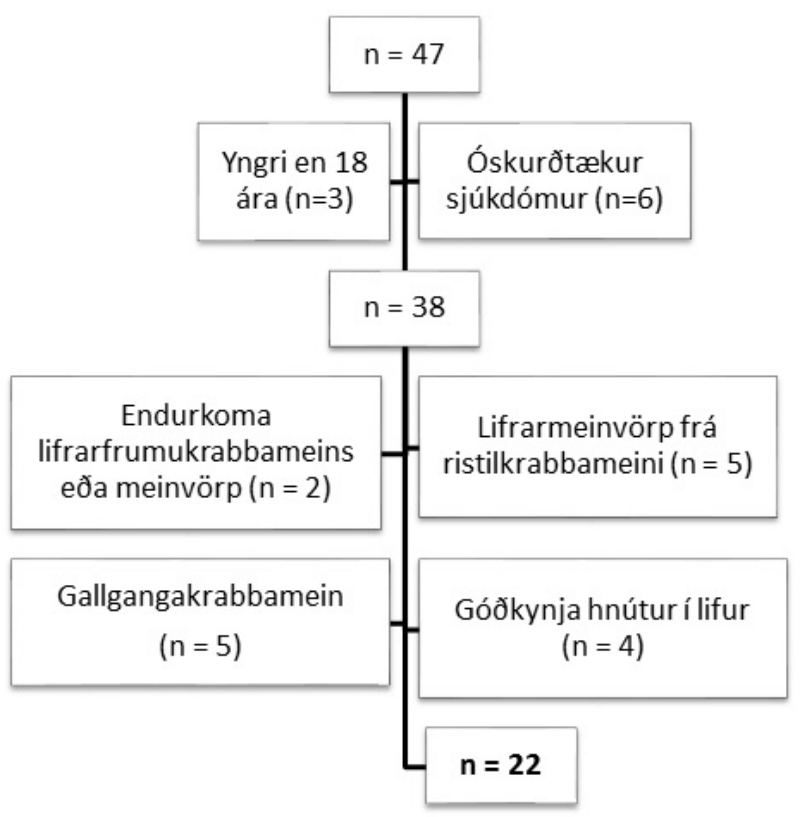

Mynd 2. Með leit í sjúkra- og aðgerðarskrám Landspítalans fundust 47 einstaklingar en einungis 22 uppfylltu skilyrði rannsóknarinnar. 
Tafla III. Lýsing pýðis. Sjúklingar sem gengust undir aðgerð vegna lifrarfrumukrabbameins.

\begin{tabular}{|c|c|c|}
\hline Breytur & Skilgreining & $\mathrm{N}(\%)$ \\
\hline \multirow[t]{2}{*}{ Kyn } & $\mathrm{Kk}$ & $18(82)$ \\
\hline & Kvk & $4(18)$ \\
\hline \multirow[t]{2}{*}{ Alfa-fetóprótein (AFP) } & Mælt & $18(82)$ \\
\hline & Hækkað $(>5,7)$ & 7 (39) \\
\hline \multirow[t]{7}{*}{ Áhættupættir skorpulifur } & Til staðar & $7(39)$ \\
\hline & Áfengi & 2 \\
\hline & Sjálfsofnæmislifrarbólga & 1 \\
\hline & Lifrarbólga B & 0 \\
\hline & Lifrarbólga C & 1 \\
\hline & Járnofhleðsla & 2 \\
\hline & Fitulifur & 1 \\
\hline \multirow[t]{6}{*}{ Bandvefsmyndun } & Já & $5(23)$ \\
\hline & Stigun & \\
\hline & 1 & 2 \\
\hline & 2 & 2 \\
\hline & 3 & 0 \\
\hline & 4 & 1 \\
\hline \multirow[t]{7}{*}{ Skorpulifur } & Já & $4(18)$ \\
\hline & Child-Pugh skor $A$ & $4(100)$ \\
\hline & Ástæða & \\
\hline & Fitulifur & 1 \\
\hline & Áfengi & 1 \\
\hline & Sjálfsofnæmislifrarbólga & 1 \\
\hline & Járnofhleðsla & 1 \\
\hline \multirow[t]{4}{*}{ ASA-flokkun } & 1 & 1 \\
\hline & 2 & $9(41)$ \\
\hline & 3 & $11(50)$ \\
\hline & 4 & 1 \\
\hline
\end{tabular}

kvæmt Clavien-Dindo ${ }^{24}$ (tafla II). Ekki komu fram upplýsingar um stig bandvefsmyndunnar í lifur á öllum meinafræðisvörum hjá sjúklingum sem ekki höfðu skorpulifur og purfti pví að endurskoða 12 sýni með tilliti til pessa. Sjúklingar með skorpulifur voru stigaðir samkvæmt Child-Pugh-skori (tafla I). Bæði heildarlegutími og legutími á gjörgæslu voru skráð en gert er ráð fyrir sólarhringslegu á gjörgæslu hjá peim sem gengust undir meiriháttar hlutabrottnám lifrar. Einnig var skráð dánartíðni 30 dögum eftir aðgerð, ári eftir aðgerð og í lok rannsóknartímabilsins.

Upplýsingar voru skráðar í forritið Microsoft Office Excel og var öll tölfræðileg úrvinnsla gerð par. Notuð var lýsandi tölfræði. Rannsóknin var framkvæmd með tilskildum leyfum frá Persónuvernd (tilv.: 2013121638TS og 2014101360TS), Vísindasiðanefnd (tilv.: VSNb2014010003/03.11) og framkvæmdastjóra lækninga á Landspítala.

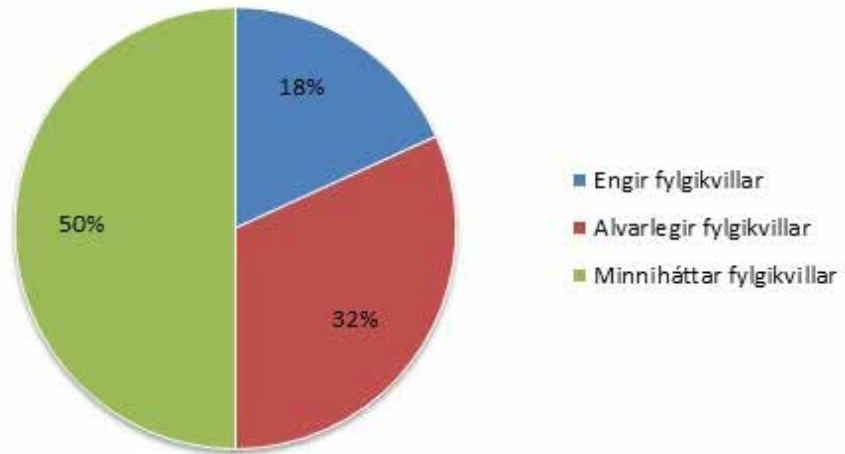

Mynd 3. Flokkun fylgikvilla eftir aðgerð samkvæmt Clavien-Dindo.

\section{Niðurstöठur}

Samkvæmt upplýsingum frá Krabbameinsskrá Íslands greindust 105 einstaklingar með lifrarfrumukrabbamein á tímabilinu. Samkvæmt leit í sjúkra- og aðgerðarskrám Landspítala voru 47 sjúklingar með greininguna lifrarfrumukrabbamein fyrir aðgerð en af peim reyndust fjórir hafa góðkynja hnút í lifur. Sex voru með óskurðtækan sjúkdóm, tveir með endurkomu lifrarfrumukrabbameins eða meinvörp, prír voru yngri en 18 ára, 5 með lifrarmeinvörp frá ristilkrabbameini, 5 með gallgangakrabbamein. Pessir einstaklingar voru útilokaðir. Alls voru pví 22 sem uppfylltu skilyrði rannsóknarinnar (mynd 2), auk peirra gengust 6 einstaklingar undir lifrarígræðslu, pessir einstaklingar voru ekki skoðaðir frekar. Раð gerir alls 28 (27\%) sem gengust undir skurðaðgerð vegna lifrarfrumukrabbameins á tímabilinu.

Upplýsingar um sjúklinga sem gengust undir hlutabrottnám á lifur (n=22) má sjá í töflu III. Karlar voru í meirihluta, eða $82 \%(n=18)$. Meðalaldur við greiningu var 68 ár (bil: 22-82). Fjórir einstaklingar, eða $18 \%$, voru með skorpulifur og voru peir allir með Child-Pugh stig A. Fimm voru með bandvefsmyndun í lifur, án skorpulifrar, og einn með langvinnan lifrarsjúkdóm án pess að bandvefsmyndun væri komin fram. Helmingur sjúklinganna var metinn í ASA-flokki 3 fyrir aðgerð og 41\% í flokki 2.

Allir sjúklingarnir fóru í myndgreiningu fyrir aðgerð, flestir fóru í tölvusneiðmynd ( $\mathrm{n}=17)$ og síðan annaðhvort segulómskoðun ( $n=6)$ eða ómskoðun (n=9). Hjá 12 manns voru gerðar tvær tegundir myndgreiningar og var algengasta samsetningin ómun og tölvusneiðmynd ( $\mathrm{n}=8$ ). Einn fór eingöngu í kviðarholsyfirlit. Einungis var fengið vefjasýni úr æxli með grófnál hjá 9 einstaklingum fyrir aðgerð.

Tólf manns, eða 55\%, fóru í svokallaða stærri lifraraðgerð (major hepatectomy) par sem prír eða fleiri lifrargeirar voru fjarlægðir. Af pessum 12 fóru prír í útvíkkaða aðgerð par sem hægri eða vinstri lifrarhelmingur var fjarlægður ásamt aðliggjandi geira frá andstæðum lifrarhelmingi. Hinir 10 fóru í aðgerð par sem einungis einn til tveir geirar voru fjarlægðir $(n=7)$ eða gerður fleygskurður $(n=3)$.

Aðgerðartími var að meðaltali 263 mínútur, par sem stysta aðgerðin var 90 mínútur og lengsta aðgerðin var 858 mínútur, eða rúmar 14 klukkustundir. Miðgildi áætlaðs blóðtaps var $1300 \mathrm{ml}$ (bil: 100-13500 ml) en tveir misstu meira en 10 lítra af blóði í aðgerð. Alls fengu 16 manns (73\%) blóðgjöf í aðgerð. Tíðni fylgikvilla 
Tafla IV. Fylgikvillar eftir aðgerð, minniháttar (Clavien-Dindo-flokkur 1-2) og alvarlegir fylgikvillar (flokkur 3-5).

\begin{tabular}{lccc}
\hline Gráda & $\begin{array}{c}\text { Stæri } \\
\text { lifraraðgerð } \\
\mathrm{n}=12(55 \%)\end{array}$ & $\begin{array}{c}\text { Minni } \\
\text { lifraraðgerð } \\
\mathrm{n}=10(45 \%)\end{array}$ & Alls $\mathrm{n}=22$ \\
\hline 0 & 3 & 1 & $4(18 \%)$ \\
\hline Minniháttar fylgikvillar & 1 & & \\
\hline 1 & 3 & 4 & 5 \\
\hline 2 & 0 & 3 & 61 \\
\hline Alvarlegir fylgikvillar & 1 & 2 & 2 \\
\hline $3 a$ & 0 & 0 & 1 \\
\hline $3 b$ & 3 & 0 & 0 \\
\hline $4 a$ & 1 & 0 & 3 \\
\hline $4 b$ & & 0 & 1 \\
\hline 5 & 0 & & \\
\hline
\end{tabular}

í aðgerð var 23\% og var um að ræða blæðingu (n=3), rof á pind $(n=1)$ og gallvegaskaða $(n=1)$.

Flest æxlin, eða 64\%, voru staðsett í hægri lifrarlappa. Meðalstærð æxla var $8,5 \mathrm{~cm}$ og var minnsta æxlið $3 \mathrm{~cm}$ en pað stærsta $22 \mathrm{~cm}$. Meðalstærð æxla hjá peim sem fóru í stærri lifraraðgerð var 10,4 cm. Alls 14 manns (64\%) voru með stór æxli, pað er að segja æxlisstærð meiri en $5 \mathrm{~cm}$. Fjarlægð æxlis frá skurðbrún var að meðaltali 0,6 cm en æxlisvöxtur fannst í skurðbrún í tveimur tilfellum og var skurðbrún minni en $1 \mathrm{~cm}$ í 11 tilfellum. Í tveimur tilfellum var fjarlægð frá skurðbrún ekki skráð. Af peim 13 einstaklingum par sem skurðbrún var minni en $1 \mathrm{~cm}$ fóru tveir í fleygskurð. Um fjölhreiðrasjúkdóm (satellite tumors) var að ræða í 9 tilfellum.

Fylgikvilla eftir aðgerð má sjá í töflu IV en alls fengu 18 af 22 fylgikvilla, eða $82 \%$. Par af voru 7 sem fengu alvarlega fylgikvilla, pað er að segja Clavien Dindo-gráða 3-5 (mynd 3, tafla II) og af peim voru 5 sem höfðu gengist undir stærri lifraraðgerð. prír purftu enduraðgerð, tveir vegna blæðingar og einn vegna gallvegaskaða. Miðgildi legutíma var 12 dagar en lengsta legan var 105 dagar. Allir 12 einstaklingarnir sem gengust undir stærri lifraraðgerð lágu á gjörgæslu í sólarhring eftir aðgerð. Af peim voru fjórir endurinnlagðir á gjörgæslu. Tveir sem gengust undir minni lifraraðgerð voru lagðir inn á gjörgæslu í sólarhring eftir aðgerð. Lengst lá sjúklingur á gjörgæslu í 49 daga eftir aðgerð.

Enginn lést innan 30 daga frá aðgerð en einn sjúklingur lést í legu og var pað 48 dögum eftir aðgerð. Fimm létust innan árs frá aðgerð (23\%) og voru tveir peirra með endurkomu á sjúkdómi. Í lok rannsóknartímabils höfðu alls 12 (55\%) fengið endurkomu sjúkdóms og höfðu 6 peirra farið í stærri lifraraðgerð, fjórir í geiranám og tveir í fleygskurð. Ekki var marktækur munur á skurðbrún peirra sem fengu endurkomu á sjúkdómi miðað við pá sem ekki fengu endurkomu. Alls voru 11 einstaklingar (50\%) látnir við lok rannsóknartímabils, par af 8 með endurkomu sjúkdóms.

\section{Umræða}

Lifrarfrumukrabbamein er meðal algengustu krabbameina í heimi. Tíðni er hins vegar háð tíðni skorpulifrar sem hérlendis er með pví lægsta sem pekkist í heiminum. ${ }^{25}$ Horfur peirra sem greinast með lifrarfrumukrabbamein eru hins vegar slæmar, meðal annars vegna pess hve seint sjúkdómurinn greinist. Hlutfall skurðtækra einstaklinga með lifrarfrumukrabbamein í pessari rannsókn reyndist vera sambærilegt erlendum rannsóknum.

Um $80 \%$ peirra sem greinast með lifrarfrumukrabbamein á heimsvísu hafa skorpulifur en samkvæmt íslenskri rannsókn frá 2001 voru einungis 32\% peirra sem greindust á árunum 1984-1998 með skorpulifur. ${ }^{3}$ Mikilvægt er að fylgjast vel með sjúklingum með skorpulifur vegna áhættu á myndun lifrarfrumukrabbameins í peim sjúklingahópi. Líkur á lifrarfrumukrabbameini hjá einstaklingi með skorpulifur eru metnar $6 \%$ á priggja ára tímabili og $9 \%$ á 5 ára tímabili. ${ }^{26}$ Við skimun pessa sjúklingahóps eru meiri líkur á að æxli sem greinast séu minni og möguleiki á aðgerð með lifrarígræðslu eða hlutabrottnámi meiri. Lifrarfrumukrabbamein sem greinist án pess að skorpulifur sé til staðar er oftast stærra par sem einstaklingurinn fær ekki einkenni fyrr en seint í sjúkdómsferlinu. ${ }^{27}$ Í pessari rannsókn reyndust einungis fjórir af 22 vera með skorpulifur og meðalstærð æxla var $8,5 \mathrm{~cm}$, sem eykur líkur á fylgikvillum í og eftir aðgerð, æxlisvexti í skurðbrún og æðainnvexti. Stærri æxli krefjast umfangsmeiri aðgerðar á lifur og algengara er að stærri æxli vaxi í eða að skurðbrún. Einnig eru meiri líkur á endurkomu sjúkdóms og innvexti í æðar ef um stór æxli er að ræða. ${ }^{28}$ Petta er ein meginástæða fyrir takmörkunum í stærð pegar kemur að lifrarígræðslu.

Fylgikvillatíðni við hlutabrottnám á lifur hefur almennt verið há en batnað með bættri skurðtækni og stuðningsmeðferð. Mikill meirihluti sjúklinga í pessari rannsókn, eða $82 \%$, fengu fylgikvilla eftir aðgerð og hjá 32\% peirra var um alvarlega fylgikvilla að ræða (Clavien-Dindo-gráða 3-5, tafla II). Umfang aðgerðar hefur áhrif á fylgikvillatíðni, pví stærri sem aðgerðin er pví meiri hætta á fylgikvillum. ${ }^{29}$ Meira en helmingur einstaklinga í pessari rannsókn, 64\%, voru með stór æxli, pað er stærri en 5 cm, og 55\% einstaklinga gengust undir stærri lifraraðgerð. Petta getur skýrt hærri tíðni fylgikvilla hér á landi samanborið við erlendar rannsóknir. Annar páttur er að fylgikvillar eins og fleiðruvökvi og samfall á lungnablöðrum verða hjá nær öllum sjúklingum sem gangast undir lifraraðgerð. Margir rannsakendur telja petta pví ekki til fylgikvilla, sem getur skýrt mun á fylgikvillum í flokki Clavien-Dindo 1-2. ${ }^{30}$

Margir pættir geta haft áhrif á endurkomu, til dæmis æxlisvöxtur í skurðbrún, innvöxtur krabbameins í æðar og æxlishreiður umhverfis meginæxli. Mikilvægt er að leitast við að gera aðgerðir á heilum lifrargeirum til að möguleg æxlishreiður fylgi með par sem vöxtur lifrarfrumukrabbameins verður eftir æðastilkum innan lifrar. Æxlishreiður eru ekki alltaf sýnileg á myndrannsóknum fyrir aðgerð.

Fáir sjúklingar greinast á Íslandi með lifrarfrumukrabbamein á ári hverju. Afturskyggnar rannsóknir eru takmarkaðar. Par er 
hægt að fá grófa mynd af stærðum en alltaf er erfitt að fá nákvæmar upplýsingar par sem skráningu er oft ábótavant. Mikilvægt er að peir sem greinast séu ræddir á svokölluðum samráðsfundum sem er mikilvægur vettvangur par sem margar sérgreinar koma að og geta gefið ráðleggingar varðandi meðferð. Einnig er mikilvægt að hefja framskyggna skráningu í gagnagrunn á Íslandi yfir alla pá sem greinast með lifrarfrumukrabbamein, par sem skráðar eru upplýsingar um greiningu og meðferð. Með peim hætti fáum við mælikvarða sem hjálpar okkur að meta hvernig meðferð hérlendis er háttað miðað við pau lönd sem við berum okkur saman við.

\section{Pakkir}

Höfundar pakka Ionu Sjöfn Huntingdon-Williams fyrir hönnun og leyfi til notkunar á mynd af skiptingu lifrar í geira (mynd 1).

\section{Heimildir}

1. Llovet JM, Burroughs A, Bruix J. Hepatocellular carcinoma. Lancet 2003; 362: 1907-17.

2. Davis GL, Dempster J, Meler JD, Orr DW, Walberg MW, Brown B, et al. Hepatocellular carcinoma: management of an increasingly common problem. Proc (Bayl Univ Med Cent) 2008; 21: 266-80.

3. Ragnarsdóttir B, Jónasson JG, Tulinius $\mathrm{H}$, Olafsson $\mathrm{S}$. Lifrarfrumukrabbamein á Íslandi. Læknablaðið 2001; 87: 527-31.

4. Kalaitzakis E, Gunnarsdottir SA, Josefsson A, Björnsson E. Increased risk for malignant neoplasms among patients with cirrhosis. Clin Gastroenterol Hepatol 2011; 9: 168-74.

5. Belghiti J, Fuks D. Liver resection and transplantation in hepatocellular carcinoma. Liver Cancer 2012; 1: 71-82.

6. Poon RT-P, Fan S-T, Tsang FH-F, Wong J. Locoregional therapies for hepatocellular carcinoma: a critical review from the surgeon's perspective. Ann Surg 2002; 235: 46686.

7. Bonadio I, Colle I, Geerts A, Smeets P, Berardi G, Praet M, et al. Liver transplantation for hepatocellular carcinoma comparing the Milan, UCSF, and Asan criteria: long-term follow-up of a Western single institutional experience. Clin Transplant 2015; 29: 425-33.

8. Pompili M, Francica G, Ponziani FR, Iezzi R, Avolio AW. Bridging and downstaging treatments for hepatocellular carcinoma in patients on the waiting list for liver transplantation. World J Gastroenterol 2013; 19: 7515-30.

9. Song T. Recent advances in surgical treatment of hepatocellular carcinoma. Drug Discov Ther 2015; 9: 31930.

10. Fong Y, Sun RL, Jarnagin W, Blumgart LH. An analysis of 412 cases of hepatocellular carcinoma at a Western center. Ann Surg 1999; 229: 790-9-800.

11. Yu SJ. A concise review of updated guidelines regarding the management of hepatocellular carcinoma around the world: 2010-2016. Clin Mol Hepatol 2016; 22: 7-17.
12. Ferrero A, Viganò L, Polastri R, Muratore A, Eminefendic H, Regge D, et al. Postoperative Liver Dysfunction and Future Remnant Liver: Where Is the Limit? World J Surg 2007: 31: 1643-51.

13. Nakayama H, Takayama T. Role of surgical resection for hepatocellular carcinoma based on Japanese clinical guidelines for hepatocellular carcinoma. World J Hepatol 2015; 7: 261-9.

14. Germain T, Favelier S, Cercueil J-P, Denys A, Krausé D, Guiu B. Liver segmentation: practical tips. Diagn Interv Imaging 2014; 95: 1003-16.

15. Hasegawa K, Kokudo N, Imamura H, Matsuyama Y, Aoki $\mathrm{T}$, Minagawa $\mathrm{M}$, et al. Prognostic impact of anatomic resection for hepatocellular carcinoma. Ann Surg 2005; 242: 252-9.

16. Jin $\mathrm{S}, \mathrm{Fu} \mathrm{Q}$, Wuyun G, Wuyun T. Management of posthepatectomy complications. World J Gastroenterol 2013; 19: 7983-91.

17. Itoh $\mathrm{S}$, Uchiyama $H$, Kawanaka $H$, Higashi T, Egashira A, Eguchi D, et al. Characteristic risk factors in cirrhotic patients for posthepatectomy complications: comparison with noncirrhotic patients. Am Surg 2014; 80: 166-70.

18. Mullen JT, Ribero D, Reddy SK, Donadon M, Zorzi D, Gautam S, et al. Hepatic insufficiency and mortality in 1,059 noncirrhotic patients undergoing major hepatectomy. J Am Coll Surg 2007; 204: 854-62.

19. Chang C-M, Yin W-Y, Su Y-C, Wei CK, Lee CH, Juang SY, et al. Preoperative risk score predicting 90-day mortality after liver resection in a population-based study. Medicine (Baltimore). 2014; 93: e59.

20. Hyder O, Pulitano C, Firoozmand A, Dodson R, Wolfgang CL, Choti MA, et al. A risk model to predict 90-day mortality among patients undergoing hepatic resection. J Am Coll Surg 2013; 216: 1049-56.

21. Belghiti J, Kianmanesh R. Surgical treatment of hepatocellular carcinoma. HPB (Oxford). 2005; 7: 42-9.
22. Yamanaka N, Okamoto E, Toyosaka A, Mitunobu M, Fujihara S, Kato T, et al. Prognostic factors after hepatectomy for hepatocellular carcinomas. A univariate and multivariate analysis. Cancer 1990; 65: 1104-10.

23. El-Serag HB, Marrero JA, Rudolph L, Reddy KR. Diagnosis and treatment of hepatocellular carcinoma. Gastroenterology 2008; 134: 1752-63.

24. Dindo D, Demartines N, Clavien P-A. Classification of surgical complications: a new proposal with evaluation in a cohort of 6336 patients and results of a survey. Ann Surg 2004; 240: 205-13.

25. Gunnarsdottir SA, Olsson R, Ólafsson S, Cariglia N, Westin J, Thjódleifsson B, et al. Liver cirrhosis in Iceland and Sweden: incidence, aetiology and outcomes. Scand J Gastroenterol 2009; 44: 984-93

26. Singal AG, Conjeevaram HS, Volk ML, Fu S, Fontana RJ, Askari F, et al. Effectiveness of Hepatocellular Carcinoma Surveillance in Patients with Cirrhosis. Cancer Epidemiol Biomarkers Prev 2012; 21: 793-9.

27. Bhaijee F, Krige JEJ, Locketz ML, Kew MC. Liver resection for non-cirrhotic hepatocellular carcinoma in South African patients. S Afr J Surg 2011; 49: 68-74.

28. Shah SA, Wei AC, Cleary SP, Yang I, McGilvray ID, Gallinger S, et al. Prognosis and results after resection of very large $(\geq 10 \mathrm{~cm})$ hepatocellular carcinoma. J Gastrointest Surg 2007; 11: 589-95.

29. Zhong JH, Pan LH, Wang YY, Cucchetti A, Yang T, You $\mathrm{XM}$, et al. Optimizing stage of single large hepatocellular carcinoma - A study with subgroup analysis by tumor diameter. Medicine (Baltimore) 2017; $96: 15$ (e6608)

30. Doussot A, Lim C, Lahat E, Salloum C, Osseis M, Gavara CG, et al. Complications after Hepatectomy for Hepatocellular Carcinoma Independently Shorten Survival: A Western, Single-Center Audit. Ann Surg Oncol 2017; 24: 1569-78.

\section{ENGLISH SUMMARY}

\section{Surgical treatment of hepatocellular carcinoma at Landspitali The National University Hospital of Iceland $1993-2012$}

\section{Anna Kristín Höskuldsdóttir ${ }^{1}$, Sigurður Blöndal ${ }^{1,2}$, Jón Gunnlaugur Jónasson ${ }^{2,3}$, Kristín Huld Haraldsdóttir ${ }^{1}$}

Introduction: Hepatocellular carcinoma (HCC) is one of the most common cancers in the world. The incidence in Iceland is very low probably due to a low prevalence of cirrhosis. The only curative treatment is surgery, either transplant or resections, but only about $30 \%$ of patients are operable at the time of diagnosis. The aim of this study was to determine the number of patients who undergo liver resection due to $\mathrm{HCC}$ and to investigate outcomes after surgery at Landspitali University Hospital in Iceland.

Material and methods: A retrospective study of all HCC patients, 18 years of age or older, who underwent surgical resection at Landspitali University Hospital from January $1^{\text {st }} 1993$ to December $31^{\text {st }} 2012$. Data was collected from clinical records. Descriptive statistical analysis was used.

Results: During the time period 22 patients were operated with a liver resection and of those patients 12 (55\%) had a major hepatectomy. 105 individuals in total were diagnosed with $\mathrm{HCC}$ in the time period, six patients had transplantation which results in 28 operations (27\%). The average size of the tumors was $8.5 \mathrm{~cm}$ (3-22). Four individuals had cirrhosis. The frequency of intra-operative complications was $23 \%$ and post-operative complications $32 \%$ (Clavien-Dindo grade III and IV). A total of three individuals needed reoperation. The 30 day mortality rate was $0 \%$. Twelve (55\%) individuals were diagnosed with recurrence during the research period and eleven died. The one year mortality rate was $23 \%$.

Conclusion: The proportion of operable individuals with HCC in Iceland is low, few of whom have cirrhosis or other chronic liver disease. The mortality rate is comparable to other researches but the frequency of serious complications is higher probably due to tumor size.

${ }^{1}$ University Hospital of Iceland, Depts of Abdominal surgery and ${ }^{3}$ Pathology, ${ }^{2}$ University of Iceland, Faculty of Medicine.

Key words: hepatocellular carcinoma, HCC, liver surgery, major hepatectomy.

Correspondence: Anna Kristín Höskuldsdóttir, annakh26@gmail.com 